\title{
Obesitas pada Pekerja Minyak dan Gas
}

\author{
Obesity among Oil and Gas Workers
}

\author{
Dilla Christina, Ratu Ayu Dewi Sartika
}

Departemen Gizi Kesehatan Masyarakat Fakultas Kesehatan Masyarakat Universitas Indonesia

\begin{abstract}
Abstrak
Beberapa tahun terakhir angka obesitas di Indonesia cenderung meningkat. Obesitas terjadi akibat ketidakseimbangan antara asupan dan output energi dalam jangka waktu cukup lama. Tujuan penelitian ini adalah untuk mengetahui faktor risiko kejadian obesitas pada pekerja on shore di perusahaan minyak dan gas. Desain penelitian ini adalah studi cross sectional. Sampel yang diteliti adalah seluruh pekerja on shore (laki-laki maupun perempuan) berusia $35-55$ tahun yang sesuai dan memenuhi kriteria inklusi dan ekslusi yang telah ditetapkan $(n=378)$. Hasil penelitian menunjukkan bahwa prevalensi obesitas (IMT $\geq 25 \mathrm{~kg} / \mathrm{m}^{2}$ ) pada pekerja on-shore sebesar $49,5 \%$. Variabel umur, tingkat pendidikan, status pegawai, asupan energi, karbohidrat, dan serat memiliki hubungan signifikan dengan kejadian obesitas (nilai $p<0,05$ ). Faktor yang paling dominan berhubungan dengan kejadian obesitas adalah tingkat pendidikan (OR $=2,85 ; 95 \% \mathrm{Cl}=1,240-6,502)$. Tingginya prevalensi obesitas pada pekerja memerlukan perhatian yang lebih serius dari pihak perusahaan dalam menanggulangi masalah obesitas melalui upaya peningkatan program komunikasi, informasi, dan edukasi gizi yang lebih terarah dan terprogram serta perlu dilakukan sosialisasi untuk memantau berat badan dan lingkar pinggang-panggul secara rutin untuk mencegah timbulnya penyakit jantung koroner.
\end{abstract}

Kata kunci: Obesitas, pekerja, asupan energi

\begin{abstract}
In the last few years the incidence of obesity in Indonesia tends to increase. Obesity is caused by an imbalance between energy intake and output in a long term. The purpose of this study was to identify risk factors in the incidence of obesity of the workers on-shore oil and gas companies. This research designed by cross sectional study. The subject of this research was on shore workers of oil and gas company (male and female) aged $35-55$ years old in East Kalimantan and were eligible for inclusion and exclusion criteria $(n=378)$. The results showed that the prevalence of obesity of on-
\end{abstract}

shore workers was as high as $49.5 \%\left(\mathrm{BMl} \geq 25 \mathrm{~kg} / \mathrm{m}^{2}\right)$. Age, level of education, employement status, energy, carbohydrate, and fiber intake were associated with obesity ( $p$ value $<0,05)$. The most dominant factor associated with obesity was level of education $(\mathrm{OR}=2,85 ; 95 \% \mathrm{Cl}=1,240$ $6,502)$. The high prevalence of obesity in the workers need more serious attention from the company in overcoming the problem of obesity, by enhancing the EIC program with more focused and sustainable, and need to socialize monitoring of body weight and waist-hip circumference regularly to prevent coronary heart disease.

Key words: Obesity, workers, energy intake

\section{Pendahuluan}

Gizi lebih dan obesitas telah menjadi epidemi kesehatan masyarakat global selama hampir satu dekade dan mulai menjadi perhatian publik karena hubungannya dengan berbagai kondisi kesehatan kronis. ${ }^{1}$ Epidemi tersebut terjadi akibat perubahan yang sangat cepat akan gaya hidup dan perilaku di negara berkembang, antara lain adanya perubahan aktivitas fisik dan diet yang diikuti dengan perkembangan ekonomi. Selain itu, obesitas juga berkaitan dengan populasi di daerah urban dan tingginya status sosial ekonomi. ${ }^{2}$ Obesitas adalah suatu keadaan menumpuknya lemak dalam tubuh melebihi batas normal. Batasan seseorang dapat dikatakan obesitas diukur dari perbandingan berat badan dan tinggi badan. Obesitas merupakan hasil dari ketidakseimbangan asupan energi dan pengeluaran energi. Penentuan obesitas menggunakan indeks massa tubuh

Alamat Korespondensi: Ratu Ayu Dewi Sartika, Departemen Gizi Kesehatan Masyarakat, Gd. F Lt. 2 FKM Universitas Indonesia, Kampus Baru UI Depok 16424, Hp.08568470670,e-mail:ayu_fkm_ui@yahoo.com 
(IMT), hasil perhitungan berat badan (dalam kilogram) dibagi kuadrat tinggi badan (dalam meter). Faktor risiko yang dapat menyebabkan kelebihan berat badan dan obesitas di tempat kerja antara lain pekerjaan dengan aktivitas atau gerakan yang sedikit sebagai bagian dari sedentary life style, desain tempat kerja yang tidak dibentuk untuk pergerakan bebas, kesempatan yang terbatas untuk melakukan aktivitas fisik selama jam kerja serta pilihan makanan yang tidak sehat di kantin. ${ }^{3}$

Obesitas telah menjadi suatu tantangan kesehatan pada abad 21 ini dengan peningkatan mortalitas serta menghabiskan biaya yang cukup besar. ${ }^{4}$ Kejadian obesitas dapat meningkatkan masalah kesehatan kronis seperti penyakit jantung, diabetes tipe 2, hipertensi, dan lain-lain. Berdasarkan hasil Survei Kesehatan Rumah Tangga (SKRT) tahun 2004, prevalensi penduduk yang mengalami kelebihan berat badan meningkat dari $16,2 \%$ pada tahun 2001 menjadi $20,6 \%$ pada tahun 2004. ${ }^{5}$ Data Riset Kesehatan Dasar (Riskesdas) tahun 2007 menunjukkan prevalensi nasional obesitas umum pada penduduk berusia $\geq 15$ tahun adalah $10,3 \%$ (lakilaki $13,9 \%$, perempuan $23,8 \%$ ). Faktor risiko obesitas adalah pendidikan tinggi, pendapatan/sosial ekonomi tinggi dan tingginya konsumsi makanan berisiko/ lemak. 6

Gaya hidup pekerja minyak dan gas (migas) (on shore) antara lain kebiasaan olahraga tidak teratur, kebiasaan merokok, serta asupan tinggi kalori dan lemak. Perusahaan menyediakan makanan secara prasmanan bagi pekerja meliputi sarapan, makan siang, makan malam, dan 2 kali makanan selingan. Makanan dan minuman yang dapat diambil sesukanya menyebabkan tidak terkontrolnya asupan makan pekerja yang berdampak pada ketidakseimbangan antara asupan kalori dengan pengeluaran energi. Jika keadaan ini berlangsung terusmenerus dan ditambah dengan aktivitas fisik yang kurang maka pekerja akan semakin berisiko untuk mengalami kelebihan berat badan dan obesitas. Penelitian ini bertujuan untuk mengetahui faktor risiko kejadian obesitas pada pekerja on shore di perusahaan migas.

\section{Metode}

Desain studi yang digunakan adalah desain studi cross sectional. Populasi adalah seluruh pekerja migas on shore di wilayah Kalimantan Timur, sedangkan subjek adalah pekerja migas on shore pada perusahaan X di wilayah Kalimantan Timur. Kriteria inklusi meliputi pekerja tetap, telah bekerja minimal 1 tahun. Kriteria eksklusi adalah subjek menderita diabetes melitus, pernah dioperasi jantung, wanita yang sedang hamil atau menggunakan pil, suntik dan susuk Keluarga Berencana (KB) serta tidak bersedia ikut selama penelitian berlangsung. Berdasarkan 388 responden, terdapat 378 responden yang sesuai dijadikan subjek penelitian. Cara pengambilan sampel dilakukan dengan pendekatan metode simple random sampling (acak sederhana) berdasarkan daftar on duty pekerja. Setiap pekerja memiliki kesempatan yang sama untuk terpilih atau tidak terpilih sebagai sampel penelitian.

Penentuan obesitas menggunakan IMT berdasarkan pengukuran berat badan $(\mathrm{kg})$ dibagi kuadrat tinggi badan $\left(\mathrm{m}^{2}\right)$. Status gizi untuk penduduk Asia dikelompokkan menjadi kurang $\left(<18,50 \mathrm{~kg} / \mathrm{m}^{2}\right)$, normal $(18,50-22,99$ $\left.\mathrm{kg} / \mathrm{m}^{2}\right)$, risiko obese $\left(23,00-24,99 \mathrm{~kg} / \mathrm{m}^{2}\right)$, obese tipe 1 $\left(25,00-29,99 \mathrm{~kg} / \mathrm{m}^{2}\right)$, dan obese tipe $2(\geq 30,00$ $\left.\mathrm{kg} / \mathrm{m}^{2}\right) .^{2}$ Penentuan obesitas dikelompokkan menjadi obese (IMT $\left.\geq 25 \mathrm{~kg} / \mathrm{m}^{2}\right)$ dan tidak obese $\left(<25 \mathrm{~kg} / \mathrm{m}^{2}\right) .{ }^{7}$ Variabel terikat adalah obesitas, sedangkan variabel bebas yaitu karakteristik individu (umur, jenis kelamin, tingkat pendidikan, pengetahuan, dan status pegawai) serta karakteristik perilaku subjek (asupan energi, lemak, serat, kolesterol, kebiasaan merokok, dan olahraga). Kebiasaan merokok responden dibagi menjadi perokok, bukan perokok, dan pernah merokok (responden pernah merokok dan telah berhenti sejak lebih dari 1 tahun yang lalu). Kebiasaan olahraga responden dibagi menjadi rutin dan tidak rutin. Olahraga rutin/teratur dapat dilakukan di rumah atau saat di tempat kerja yang dilakukan secara terus-menerus, ritmis, dan bersifat aerobik, seperti berjalan, bersepeda, tenis, badminton, voli dengan frekuensi 3 - 5 kali/minggu selama $15-60$ menit/kegiatan.

Sebelum pelaksanaan penelitian, dilakukan pelatihan terhadap anggota peneliti dan uji coba kuesioner untuk melakukan validasi terhadap kuesioner yang digunakan. Penilaian asupan makan secara kualitatif dengan menanyakan kebiasaan makan subjek menggunakan kuesioner kualitatif frekuensi, sedangkan data kuantitatif diperoleh dengan metode tanya ulang (recall $1 \times 24$ jam). Pengukuran berat badan menggunakan timbangan injak digital Seca (ketelitian 0,1 kg), sedangkan tinggi badan diukur dengan microtoise (ketelitian 0,1 cm). Data asupan makanan yang diperoleh dari data recall makanan diolah dan dianalisis dengan program Nutrisoft tahun 2003. Analisis data statistik meliputi analisis univariat, bivariat, dan multivariat.

\section{Hasil}

Jumlah responden pada penelitian ini sebanyak 378 orang. Sebagian besar responden berumur $>40$ tahun $(79,4 \%)$ dengan rata-rata umur 46,78 tahun (minimal 26,20 tahun, maksimal 54,80 tahun). Sebagian besar responden memiliki latar belakang D3/S1/S2 (91,0\%), status nonstaf $(63,2 \%)$, memiliki pengetahuan gizi dan kesehatan cukup $(61,4 \%)$, tidak melakukan olahraga rutin $(74,6 \%)$ serta bukan perokok $(61,1 \%)$. Rata-rata IMT responden sebesar $25,28 \pm 3,12 \mathrm{~kg} / \mathrm{m}^{2}$ (minimal 17,37 $\mathrm{kg} / \mathrm{m}^{2}$, maksimal $37,89 \mathrm{~kg} / \mathrm{m}^{2}$ ). Proporsi tertinggi adalah obese (tipe 1 dan tipe 2) sebesar 49,5\%, risiko obesitas 
$(32,0 \%)$, normal $(16,9 \%)$, dan kurang $(1,6 \%)$ (Lihat Tabel 1).

Tabel 2 menunjukkan adanya hubungan signifikan antara umur, pendidikan, dan status pegawai dengan obesitas (nilai $\mathrm{p}<0,05$ ). Rata-rata asupan energi responden sebesar 1.934,24 $\pm 571,50 \mathrm{kkal} / \mathrm{hari}, 95 \% \mathrm{CI}=$ $1.770,01 ; 1.886,92)$, sedangkan asupan karbohidrat dan lemak sebesar $52,01 \%$ dan $32,73 \%$ dari energi total. Rata-rata asupan protein, serat, dan kolesterol masingmasing sebesar 47,55 g/hari, 12,77 g/hari, dan 366,43 $\mathrm{mg} /$ hari. Hasil penelitian menunjukkan adanya hubungan signifikan antara asupan energi, karbohidrat, dan serat dengan kejadian obesitas (nilai $\mathrm{p}<0,05$ ).

Pekerja yang berpendidikan tinggi (lebih dari sama dengan SMA) berisiko mengalami obesitas 2,85 kali lebih tinggi dibandingkan pekerja dengan yang berpendidikan rendah (SMA kebawah), setelah dikontrol dengan variabel umur, status pegawai, asupan energi, dan serat (Lihat Tabel 3).

\section{Pembahasan \\ Obesitas}

Prevalensi obesitas (IMT $\geq 25 \mathrm{~kg} / \mathrm{m}^{2}$ ) sebesar $49,5 \%$. Menurut Profil Kesehatan Indonesia tahun 2004, persentase penduduk dewasa dengan IMT $>25 \mathrm{~kg} / \mathrm{m}^{2}$ adalah $16,2 \% .{ }^{8}$ Berdasarkan data Riskesdas prevalensi obesitas untuk umur $\geq 15$ tahun sebesar $10,3 \% .^{6}$ Faktor lingkungan sosial yang menjadi faktor risiko terjadinya obesitas adalah pendidikan tinggi $(\mathrm{OR}=2,07 ; 95 \% \mathrm{CI}=$ $2,021-2,120)$, pendapatan/sosial ekonomi tinggi $(\mathrm{OR}=$ $1,61 ; 95 \% \mathrm{CI}=1,577-1,650)$, dan faktor perilaku (konsumsi frekuensi tinggi makanan berisiko lemak) $(\mathrm{OR}=$ $1,17 ; 95 \% \mathrm{CI}=1,113-1,227)$. Obesitas disebabkan oleh ketidakseimbangan antara energi yang masuk dan keluar. Jika asupan energi berlebih terjadi dalam jangka waktu lama ditambah dengan kegiatan aktivitas fisik rendah maka tidak tertutup kemungkinan akan menimbulkan masalah di kemudian hari. Obesitas, dislipidemia, dan hipertensi pada pekerja migas mengalami kenaikan dari tahun ke tahun. Ketiga faktor risiko ini potensial untuk berkembang menjadi penyakit jantung koroner (PJK). Data medical check up tahunan menunjukkan terjadi peningkatan jumlah penderita PJK dari tahun 2003 sebesar $1,32 \%$ dan pada tahun 2004 sebesar 3,92\%. ${ }^{9}$ Jika tidak ditangani dengan baik tanpa adanya intervensi dini maka angka ini akan terus meningkat dan merugikan pihak perusahaan. Tempat kerja merupakan tempat yang potensial bagi penerapan kesehatan masyarakat khususnya pada orang dewasa karena dapat menjangkau orang banyak, persebaran komunitas kerja yang menguntungkan seperti adanya dukungan teman sebaya, populasi relatif stabil, mudah mempublikasikan program kesehatan, terdapat dukungan partisipasi, dan kemudahan dalam mendapat efek timbal balik. ${ }^{3}$
Tabel 1. Distribusi Frekuensi Responden Berdasarkan Karakteristik Individu dan Perilaku

\begin{tabular}{|c|c|c|c|}
\hline Variabel & Kategori & $\mathbf{n}$ & $\%$ \\
\hline \multirow[t]{2}{*}{ Umur } & $>40$ tahun (berisiko) & 300 & 79,4 \\
\hline & $\leq 40$ tahun (tidak berisiko) & 78 & 20,6 \\
\hline \multirow[t]{3}{*}{ Pendidikan } & SMP & 11 & 2,9 \\
\hline & SMA & 23 & 6,1 \\
\hline & $\mathrm{D} 3 / \mathrm{S} 1 / \mathrm{S} 2$ & 344 & 91,0 \\
\hline \multirow[t]{2}{*}{ Status pegawai } & Staf & 139 & 36,8 \\
\hline & Nonstaf & 239 & 63,2 \\
\hline \multirow[t]{2}{*}{ Pengetahuan } & Baik & 146 & 38,6 \\
\hline & Cukup & 232 & 61,4 \\
\hline \multirow[t]{2}{*}{ Olahraga } & Tidak rutin & 282 & 74,6 \\
\hline & Rutin & 96 & 25,4 \\
\hline \multirow[t]{5}{*}{ Indeks massa tubuh } & Kurang & 6 & 1,6 \\
\hline & Normal & 64 & 16,9 \\
\hline & Risiko obesitas & 121 & 32,0 \\
\hline & Obese tipe 1 & 161 & 42,6 \\
\hline & Obese tipe 2 & 26 & 6,9 \\
\hline \multirow[t]{2}{*}{ Status merokok } & Tidak merokok & 231 & 61,1 \\
\hline & Merokok & 147 & 38,9 \\
\hline Jumlah rokok & 1 - 9 (ringan) & 32 & 21,8 \\
\hline \multirow[t]{2}{*}{ (batang per hari) } & $10-19$ (sedang) & 91 & 61,9 \\
\hline & $\geq 20$ (berat) & 24 & 16,3 \\
\hline \multirow[t]{2}{*}{ Asupan energi } & Lebih (> $2.550 \mathrm{kkal} / \mathrm{hari})$ & 61 & 16,1 \\
\hline & Cukup ( $\leq 2.550 \mathrm{kkal} / \mathrm{hari})$ & 317 & 83,9 \\
\hline \multirow[t]{2}{*}{ Asupan karbohidrat } & Lebih (> 55\% energi total) & 141 & 37,3 \\
\hline & Cukup $(\leq 55 \%$ energi total $)$ & 237 & 62,7 \\
\hline \multirow[t]{2}{*}{ Asupan protein } & Lebih (> 60 gram/hari) & 81 & 21,4 \\
\hline & Cukup ( $\leq 60$ gram/hari) & 297 & 78,6 \\
\hline \multirow[t]{2}{*}{ Asupan lemak } & Lebih $(>25 \%$ energi total) & 308 & 81,5 \\
\hline & Cukup ( $\leq 25 \%$ energi total) & 70 & 18,5 \\
\hline \multirow[t]{2}{*}{ Asupan kolesterol } & Lebih (> $300 \mathrm{mg} /$ hari) & 185 & 48,9 \\
\hline & Cukup ( $\leq 300 \mathrm{mg} /$ hari) & 193 & 51,1 \\
\hline \multirow[t]{2}{*}{ Asupan serat } & Kurang $(<20 \mathrm{~g} / \mathrm{hari})$ & 331 & 87,6 \\
\hline & Cukup ( $\geq 20 \mathrm{~g} /$ hari) & 47 & 12,4 \\
\hline
\end{tabular}

\section{Karakteristik Individu}

Sebanyak 79,4\% responden yang berumur lebih dari 40 tahun berisiko untuk menderita obesitas. Hasil analisis bivariat menunjukkan ada hubungan antara umur dengan kejadian obesitas (nilai $\mathrm{p}<0,05$ ). Responden yang berusia lebih dari 40 tahun memiliki peluang obesitas sebesar 1,88 kali lebih besar dibandingkan usia di bawah 40 tahun. Hasil penelitian ini sejalan dengan hasil penelitian Heath et al, ${ }^{10}$ yang menyatakan bahwa obesitas dan diabetes melitus tipe 2 (adultonset diabetes), sebagai faktor risiko utama PJK, umumnya terjadi setelah umur 40 tahun. Menurut penelitian Pradono, ${ }^{11}$ prevalensi penyakit tidak menular meningkat sesuai dengan pertambahan umur, terutama umur 45 tahun ke atas. Menurut Treacy, ${ }^{12}$ risiko obesitas lebih tinggi pada pria berumur di atas 35 tahun.

Sebanyak $91 \%$ responden memiliki tingkat pendidikan D3/S1/S2. Berbagai hasil menyatakan bahwa sebagian besar individu yang mengalami obesitas memiliki tingkat pendidikan tinggi. Kemungkinan hal ini berhubungan dengan tingkat penghasilan. Umumnya, semakin tinggi pendidikan seseorang maka pekerjaannya 
Tabel 2. Distribusi Frekuensi Obesitas Menurut Karakteristik Individu dan Perilaku

\begin{tabular}{|c|c|c|c|c|c|c|c|}
\hline Variabel & Kategori & Obesitas & $\%$ & Tidak Obesitas & $\%$ & OR & Nilai p \\
\hline \multirow[t]{2}{*}{ Umur } & $>40$ tahun (berisiko) & 158 & 52,7 & 142 & 47,3 & 1,88 & $0,021^{*}$ \\
\hline & $\leq 40$ tahun (tidak berisiko) & 29 & 37,2 & 49 & 62,8 & & \\
\hline \multirow[t]{2}{*}{ Pendidikan } & Tinggi (PT/Akademik) & 178 & 51,7 & 166 & 48,3 & 2,98 & $0,006^{*}$ \\
\hline & Rendah ( $\leq$ SMA) & 9 & 26,5 & 25 & 73,5 & & \\
\hline \multirow[t]{2}{*}{ Status pegawai } & Staf & 55 & 39,6 & 84 & 60,4 & 0,53 & $0,004 *$ \\
\hline & Nonstaf & 132 & 55,2 & 107 & 44,8 & & \\
\hline \multirow[t]{2}{*}{ Pengetahuan } & Baik & 75 & 51,4 & 71 & 48,6 & 1,13 & 0,598 \\
\hline & Cukup baik & 112 & 48,3 & 120 & 51,7 & & \\
\hline \multirow[t]{2}{*}{ Olahraga } & Tidak rutin & 135 & 47,9 & 147 & 52,1 & 0,78 & 0,291 \\
\hline & Rutin & 52 & 54,2 & 44 & 45,8 & & \\
\hline \multirow[t]{2}{*}{ Status merokok } & Tidak merokok & 119 & 51,5 & 112 & 48,5 & 1,23 & 0,343 \\
\hline & Merokok & 68 & 46,3 & 79 & 53,7 & & \\
\hline Jumlah rokok & 1 - 9 (ringan) & 18 & 56,3 & 14 & 43,8 & 0,75 & 0,474 \\
\hline \multirow{2}{*}{ (batang per hari) } & $10-19$ (sedang) & 40 & 44,0 & 51 & 56,0 & 1,05 & 0,896 \\
\hline & $\geq 20$ (berat) & 10 & 41,7 & 14 & 58,3 & & \\
\hline \multirow[t]{2}{*}{ Asupan energi } & Lebih (> $2.550 \mathrm{kkal} / \mathrm{hari})$ & 38 & 62,3 & 23 & 37,7 & 1,86 & $0,036^{*}$ \\
\hline & Cukup $(\leq 2.550 \mathrm{kkal} / \mathrm{hari})$ & 149 & 47,0 & 168 & 53,0 & & \\
\hline \multirow[t]{2}{*}{ Asupan karbohidrat } & Lebih (> 55\% energi total) & 80 & 56,7 & 61 & 43,3 & 1,59 & $0,033 *$ \\
\hline & Cukup $(\leq 55 \%$ energi total) & 107 & 45,1 & 130 & 54,9 & & \\
\hline \multirow[t]{2}{*}{ Asupan protein } & Lebih (> 60 gram/hari) & 43 & 53,1 & 38 & 46,9 & 1,20 & 0,531 \\
\hline & Cukup $(\leq 60$ gram/hari) & 144 & 48,5 & 153 & 51,5 & & \\
\hline \multirow[t]{2}{*}{ Asupan lemak } & Lebih ( $>25 \%$ energi total) & 150 & 48,7 & 158 & 51,3 & 0,85 & 0,597 \\
\hline & Cukup ( $\leq 25 \%$ energi total) & 37 & 52,9 & 33 & 47,1 & & \\
\hline \multirow[t]{2}{*}{ Asupan kolesterol } & Lebih (> $300 \mathrm{mg} / \mathrm{hari})$ & 87 & 47,0 & 98 & 53,0 & 0,83 & 0,357 \\
\hline & Cukup ( $\leq 300$ mg/hari) & 100 & 51,8 & 93 & 48,2 & & \\
\hline \multirow[t]{2}{*}{ Asupan serat } & Kurang $(<20$ g/hari $)$ & 155 & 46,8 & 176 & 53,2 & 2,42 & $0,01 *$ \\
\hline & Cukup ( $\geq 20 \mathrm{~g} /$ hari) & 32 & 68,1 & 15 & 31,9 & & \\
\hline
\end{tabular}

Keterangan : *signifikan (nilai $\mathrm{p}<0,05$ )

Tabel 3. Analisis Multivariat Obesitas

\begin{tabular}{lcccc}
\hline Variabel & B & OR & CI & Nilai $\mathbf{p}$ \\
\hline Umur & 0,653 & 1,922 & $1,129-3,271$ & 0,016 \\
Pendidikan & 1,046 & 2,847 & $1,240-6,502$ & 0,013 \\
Status pegawai & 0,380 & 1,462 & $0,931-2,296$ & 0,099 \\
Asupan energi & 0,559 & 1,748 & $0,964-3,171$ & 0,066 \\
Asupan serat & 0,654 & 1,923 & $0,973-3,798$ & 0,060 \\
\hline
\end{tabular}

akan semakin baik dan diikuti dengan tingkat pendapatan yang lebih tinggi. Peningkatan kesejahteraan ini akan memengaruhi gaya hidup termasuk pola makan. Kejadian obesitas sebagian besar diderita oleh seseorang dengan tingkat ekonomi tinggi karena semakin tinggi tingkat kesejahteraan dan kemakmuran seseorang maka semakin tinggi kejadian obesitas. ${ }^{13}$ Hasil uji multivariat menunjukkan bahwa responden dengan tingkat pendidikan tinggi memiliki peluang obesitas sebesar hampir 3 kali lipat dibandingkan responden berpendidikan rendah setelah dikontrol oleh variabel umur, status kepegawaian, asupan energi, dan serat. Kejadian obesitas umumnya diukur dari tingkat sosial ekonomi seperti pendidikan sehingga dibutuhkan antisipasi akan peningkatan status sosial ekonomi yang berhubungan dengan obesitas yang akan meningkatkan prevalensi penyakit kronis. ${ }^{14}$
Proporsi pekerja yang tergolong nonstaf $(63,2 \%)$ lebih banyak dibandingkan dengan staf $(36,8 \%)$. Status pegawai berhubungan dengan tingkat ekonomi responden karena secara umum jenis pegawai staf memiliki penghasilan yang lebih tinggi dibandingkan nonstaf, walaupun dalam penelitian ini tidak diperoleh informasi lengkap mengenai tingkat penghasilan responden. Responden yang termasuk kategori nonstaf memiliki peluang menderita obesitas sebesar 1,89 kali dibandingkan pekerja staf. Hasil penelitian Law, ${ }^{14}$ menunjukkan adanya hubungan positif antara tingkat kemakmuran dengan obesitas pada orang dewasa (umumnya wanita) dan anak-anak.

Sejak tahun 2003, unit medis (seksi pencegahan dan promosi kesehatan) telah melakukan upaya peningkatan pengetahuan bagi pegawai secara berkala dengan cara mengadakan kampanye pola hidup sehat, kampanye perilaku hidup sehat, promosi pencegahan penyakit, dan promosi pemeliharaan derajat kesehatan. Hasil penelitian menunjukkan bahwa sebagian besar responden memiliki pengetahuan gizi dan kesehatan cukup baik. Hal ini mungkin saja terjadi jika kampanye yang diberikan terlalu sedikit mengulas aspek gizi. Tingkat pendidikan tinggi tidak menjamin seseorang mengetahui dan memahami tentang gizi dan kesehatan. Pemberian informasi berupa penyuluhan dapat meningkatkan pengetahuan 
seseorang. Pengetahuan yang kurang dapat disebabkan oleh kurangnya informasi yang diterima atau kurangnya penyerapan dan pemahaman terhadap informasi yang diterima, yang pada akhirnya dapat menimbulkan suatu bentuk tindakan yang kurang tepat.

Sebagian besar responden $(74,6 \%)$ tidak melakukan olahraga secara rutin. Hasil Riskesdas tahun 2007 menunjukkan bahwa secara nasional hampir separuh penduduk $(48,2 \%)$ kurang melakukan aktivitas fisik. ${ }^{6}$ Aktivitas fisik secara teratur bermanfaat untuk mengatur berat badan serta menguatkan sistem jantung dan pembuluh darah. Aktivitas fisik kurang jika kegiatan kumulatif kurang dari 150 menit dalam seminggu. Responden dalam penelitian ini adalah pekerja tambang yang bekerja baik di dalam ruangan maupun lapangan (field). Hal ini kemungkinan menyebabkan sedikitnya kesempatan untuk melakukan olahraga walaupun perusahaan telah menyediakan fasilitas olahraga yang relatif lengkap. Berdasarkan jadwal kerja, ada pekerja yang pulang setiap sore hari serta pekerja dengan jadwal kerja 5 hari dan 14 hari. Hal ini tentunya dapat memengaruhi aktivitas fisik khususnya kebiasaan olahraga yang dilakukan. Bagi responden yang pulang setiap hari, waktu untuk berolahraga menjadi kendala karena sudah lelah selama seharian bekerja, sementara bagi yang tinggal di lokasi saat selesai bekerja lebih memilih istirahat dibandingkan melakukan kegiatan olahraga. Penelitian Parkes, ${ }^{15}$ menyatakan bahwa olahraga secara teratur dapat menurunkan berat badan, mengurangi stres, mengendalikan kadar gula darah, memperbaiki kadar insulin, dan mencegah diabetes tipe 2.

Proporsi obesitas lebih banyak terjadi pada responden yang tidak merokok $(61,1 \%)$. Dalam penelitian ini, responden tidak merokok yang mengalami obesitas lebih tinggi. Hal ini disebabkan seseorang yang tidak merokok memiliki nafsu makan lebih tinggi dibandingkan perokok sehingga berdampak pada kenaikan berat badan. Bekas perokok dalam penelitian ini adalah subjek yang pernah merokok dan telah berhenti sejak lebih dari 1 tahun yang lalu. Walaupun pihak perusahaan telah membatasi dan menyediakan area bebas rokok, tetapi angka perokok masih cukup tinggi (38,9\%). Hal ini kemungkinan disebabkan oleh faktor stres akibat jauh dari keluarga, saat dinas malam, berteman dengan perokok atau merasa sudah memiliki kemampuan dan kesempatan untuk membeli rokok. Perilaku merokok kelompok usia $>15$ tahun cenderung meningkat dari 32,0\% menjadi 33,4\%. ${ }^{6}$ Bila dilihat dari jumlah rokok yang dihisap responden yang merokok setiap hari, 61,9\% responden merupakan perokok sedang dengan 10 - 19 batang rokok sehari. Data SKRT tahun 2004 menunjukkan bahwa dari penduduk yang merokok, rata-rata menghisap 11 batang per hari. ${ }^{5}$

Responden dengan asupan energi lebih memiliki peluang obesitas sebesar 1,86 kali dibandingkan asupan energi cukup. Menurut Hu, 16 asupan energi yang berasal dari lemak dan karbohidrat berhubungan dengan energi pengeluaran yang lebih berpengaruh pada berat badan. Pola diet yang baik dapat mencegah dan mengatasi obesitas pada orang dewasa. ${ }^{17}$ Rata-rata asupan energi responden adalah 1.934,24 $\pm 571,50 \mathrm{kkal} /$ hari. Menurut penelitian yang dilakukan di wilayah Asia Pasifik diketahui bahwa proporsi asupan gizi penduduk Indonesia adalah nomor 3 dari bawah bila dibandingkan dengan populasi di negara Asia Pasifik lainnya. ${ }^{13}$ Angka kecukupan gizi rata-rata yang dianjurkan untuk orang Indonesia berumur 19 - 29 tahun adalah $2.550 \mathrm{kkal} / \mathrm{hari}$, umur 30 - 49 tahun adalah $2.350 \mathrm{kkal} / \mathrm{hari}$, dan umur 50 - 64 tahun adalah $2.250 \mathrm{kkal} / \mathrm{hari}$. Penyediaan makanan dilakukan dalam bentuk prasmanan (all you can eat) sehingga dapat memengaruhi seseorang untuk mengambil makanan dalam jumlah tidak terkontrol seperti konsumsi energi yang berlebih. Apalagi jika makanan yang dihidangkan adalah makanan yang disukai, padat energi dan enak maka asupan total energi semakin tidak terkontrol dengan baik.

Responden dengan asupan karbohidrat lebih memiliki peluang obesitas sebesar 1,6 kali lipat dibandingkan asupan karbohidrat cukup. Sebanyak 37\% dari total responden mengonsumsi karbohidrat $>55 \%$ energi total. Kebiasaan penduduk Indonesia dalam mengonsumsi karbohidrat memang sangat tinggi. Di negara berkembang, sebesar $80 \%$ total energi berasal dari sumber karbohidrat, sedangkan untuk negara maju umumnya kontribusi karbohidrat hanya sekitar 50\% energi total sehingga karbohidrat memiliki peran yang sangat penting dalam terjadinya obesitas. Asupan energi responden terbesar berasal dari kelompok karbohidrat $(52,01 \%)$. Secara umum, pola pangan yang baik adalah bila komposisi energi dari karbohidrat, protein, dan lemak masing-masing $50 \%$ - 65\%, 10\% - 20\%, dan $20 \%$ - 30\% tergantung umur, berat badan, dan keadaan fisiologis. ${ }^{17}$ Asupan karbohidrat sebagai penyumbang energi pada penelitian ini sudah memenuhi anjuran kecukupan karbohidrat, walaupun masih lebih rendah bila dibandingkan dengan penelitian lainnya yaitu $76,8 \%$ energi total. ${ }^{13}$

Proporsi obesitas pada subjek dengan asupan protein $>60 \mathrm{~g} /$ hari lebih tinggi dibandingkan dengan asupan < $60 \mathrm{~g} /$ hari, namun perbedaannya secara statistik tidak signifikan $(\mathrm{p}>0,05)$. Menurut Jebb, 18 studi yang mempelajari hubungan antara protein dan jenis-jenis protein dengan kejadian obesitas menunjukkan hasil yang tidak konsisten. Rata-rata asupan protein dalam penelitian ini adalah 47,55 $\pm 26,64$ gram/hari, lebih rendah bila dibandingkan dengan angka kecukupan gizi yang dianjurkan pada pria berumur di atas 18 tahun yaitu 60 gram sehari. 
Pola asupan makan di daerah penelitian ini cenderung tinggi lemak. Hal ini ditandai dengan rata-rata asupan lemak sebesar $32,73 \%$ energi total. Hasil penelitian ini masih lebih tinggi jika dibandingkan dengan penelitian lainnya yaitu $14,5 \% .{ }^{12}$ Lemak merupakan sumber energi terbesar, penghasil energi lebih besar 2,5 kali dibandingkan karbohidrat dan protein. Kontribusi energi dari lemak sebaiknya tidak melebihi $30 \%$ dan perlu upaya untuk memperbaiki komposisi asam lemak untuk mencegah timbulnya penyakit kronis. Diet rendah lemak dapat mengurangi berat badan dan memperbaiki profil lemak. ${ }^{17}$

Tingginya proporsi responden dengan asupan lemak lebih menandakan bahwa menu makanan yang disediakan oleh katering adalah menu makanan tinggi lemak khususnya lemak hewani. Hasil observasi terhadap menu yang disajikan oleh pihak katering yaitu selalu tersedia menu standar berupa menu Indonesia dan Eropa untuk sarapan, makan siang, dan makan malam yang cukup banyak mengandung lemak. Rincian setiap set menu terdiri dari 2 jenis lauk hewani (daging, ikan, atau ayam), 1 jenis lauk nabati berupa tahu/tempe dan makanan pelengkap seperti sayur, kentang rebus, dan sup. Untuk menu sarapan pagi selalu disediakan omelet, scrambled, sosis, pancake, sandwich, kentang rebus, nasi, kerupuk, telur rebus, dan roti bakar. Sebagai makanan penutup (dessert) disediakan 6 jenis makanan berupa es krim, puding, cake, dan kue-kue lainnya serta 3 macam buah segar dan 1 macam buah kaleng. Selain itu, disediakan pula menu lengkap midnight untuk pegawai yang dinas malam hari dan menu low cholesterol (pengolahan menggunakan minyak jagung dan sunflower) sebagai pilihan bagi diet rendah kolesterol. Makanan yang banyak mengandung kolesterol antara lain telur, ruminansia, susu, unggas, dan kerang-kerangan. Sterol dalam kerang dan udang sedikit memengaruhi kolesterol total, kecuali digoreng, diolah dengan mentega atau dikonsumsi dalam jumlah besar. Rekomendasi terhadap asupan kolesterol makanan adalah lebih rendah dari 300 mg/hari. ${ }^{17}$ Rata-rata asupan kolesterol responden adalah 366,43 $\pm 271,63 \mathrm{mg} /$ hari. Tingginya asupan lemak hewani diikuti dengan meningkatnya asupan kolesterol makanan.

Hasil analisis menunjukkan bahwa rata-rata asupan serat responden adalah 12,77 $\pm 7,32 \mathrm{~g} /$ hari. Asupan serat yang dianjurkan yaitu 20 gram per hari. Rendahnya konsumsi serat kemungkinan disebabkan oleh ketersediaan sumber serat (sayur dan buah) yang terbatas akibat dari persediaan buah dan sayur yang rendah. Letak perusahaan migas yang jauh dari pusat kota/pasar menimbulkan kesulitan dalam pengadaan dan penyimpanan buah dan sayur yang relatif tidak tahan lama/mudah rusak. Hasil Riskesdas tahun 2007 menunjukkan bahwa prevalensi nasional kurang makan buah dan sayur pada penduduk umur $>10$ tahun sebesar 93,6\%.6 Asupan serat dan sayur secara linear akan mengurangi asupan lemak dan garam yang akan menurunkan tekanan darah dan mencegah peningkatan obesitas. Hasil penelitian menunjukkan bahwa responden dengan asupan serat kurang memiliki peluang obesitas sebesar 2,42 kali dibandingkan asupan serat cukup. Diet tinggi serat (polisakarida) berhubungan dengan pengaturan berat badan dan pencegahan obesitas. Kebiasaan mengonsumsi beraneka ragam sayuran $3-4$ porsi/hari (terutama yang berwarna hijau tua, jingga atau kuning) dan buah $4-5$ porsi/hari menjamin kecukupan asupan zat gizi mikro. ${ }^{17}$

\section{Kesimpulan}

Proporsi kejadian obesitas (IMT $\geq 25 \mathrm{~kg} / \mathrm{m}^{2}$ ) dalam penelitian ini sebesar $49,5 \%$. Variabel umur, pendidikan, status kepegawaian, serta asupan energi, karbohidrat, dan serat memiliki hubungan signifikan dengan kejadian obesitas pada pekerja migas $(\mathrm{p}<0,05)$. Pekerja yang berpendidikan tinggi (lebih dari sama dengan SMA) mempunyai risiko mengalami obesitas 2,85 kali lebih tinggi dibandingkan pekerja berpendidikan rendah (SMA ke bawah) setelah dikontrol oleh variabel umur, status pegawai, asupan energi, dan serat.

\section{Saran}

Tingginya prevalensi obesitas pada pekerja migas memerlukan perhatian yang lebih serius dari pihak perusahaan (khususnya unit medis dan penyelenggara makanan) dalam menanggulangi masalah obesitas melalui upaya kegiatan promosi kesehatan yang dilakukan secara terus-menerus dan berkesinambungan, terutama tentang bagaimana menerapkan perilaku hidup seimbang dengan melakukan perubahan kebiasaan sedentary, seperti menjaga keseimbangan antara energi (kalori) yang masuk (makanan) dan aktivitas fisik yang cukup.

\section{Daftar Pustaka}

1. Jakicic JM, Otto AD. Physical activity considerations for the treatment and prevention of obesity. Am J Clin Nutr. 2005; 82 (suppl): 226S-9S.

2. Aekplakorn W. Trends in obesity and associations with education and urban or rural residence in Thailand. Asia Pacific J Clin Nutr. 2007; 15 : 3113-21.

3. National Institutes of Health. Obesity: the prevention, identification, assessment, and management of overweight and obesity in adults and children. National Institute for Health and Clinical Excellence, National Collaborating Centre for Primary Care; 2006.

4. Blackburn GL, Walker WA. Science-based solutions to obesity: what are the roles of academia, government, industry, and health care? Am J Clin Nutr. 2005; 82 (suppl): 207S-10S.

5. Kementerian Kesehatan Republik Indonesia. Survei kesehatan rumah tangga 2004. Jakarta: Kementerian Kesehatan Republik Indonesia; 2005. 
6. Kementerian Kesehatan Republik Indonesia. Riset kesehatan dasar. Jakarta: Kementerian Kesehatan Republik Indonesia; 2007.

7. World Health Organization Expert Consultation. Appropriate body mass index for asian populations and its implications for policy and intervention strategies. Lancet; 2004. p.157-63.

8. Kementerian Kesehatan Republik Indonesia. Profil kesehatan Indonesia 2004. Jakarta: Kementerian Kesehatan Republik Indonesia; 2006.

9. Hasanah N. Faktor-faktor yang berhubungan dengan penyakit jantung koroner pada karyawan Vico Indonesia Muara Badak, Kalimantan Timur [skripsi]. Depok: Fakultas Kesehatan Masyarakat Universitas Indonesia; 2006.

10. Heath GW, Robert HW, Juneal S, Bruce EL. Community-based exercise and weight control: diabetes risk reduction and glycemic control in Zuni Indians. Am J Clin Nutr. 1991; 53: 1642S-6S.

11. Pradono J, Hapsari D, Soematri S. Faktor berisiko yang mempengaruhi penyakit tidak menular di Jawa dan Bali. Buletin Penelitian Kesehatan. 2003; 31 (3): 166-76

12. Treacy J. Obesity. The Report of the National Taskforce on Obesity.
2005. Available from: http://www.ireland.com/newspaper/special/2005/obesity/report.pdf.

13. Soerjodibroto W. Asia Pasific menu pattern in relation to lipid abnormalities: an Indonesia persperctive. Medical Journal of Indonesia. 2004; 13: 252-7.

14. Law C. Obesity and health inequalities. The International Association For the Study of Obesity. 2006 [8 (suppl. 1): 19-22]. Available from: http://www.blackwell-synergy.com.

15. Parkes KR. Physical activity and self-rated health: interactive effects of activity in work and leisure domains. British Journal of Health Psychology. 2006; 11 (3): 533-50.

16. Hu FB, Manson JE, Willett WC. Types of dietary fat and risk of coronary heart disease: a critical review. J Am Coll Nutr. 2001; 20 (1): 5-19.

17. Perhimpunan Dokter Spesialis Kardiovaskular Indonesia Yayasan Jantung Indonesia. Pedoman makanan untuk kesehatan jantung Indonesia. Jakarta; Yayasan Jantung Indonesia: 2002.

18. Jebb SA. Dietary determinants of obesity. The International Association For the Study of Obesity. 2007; 8 (suppl. 1): 93-7. 